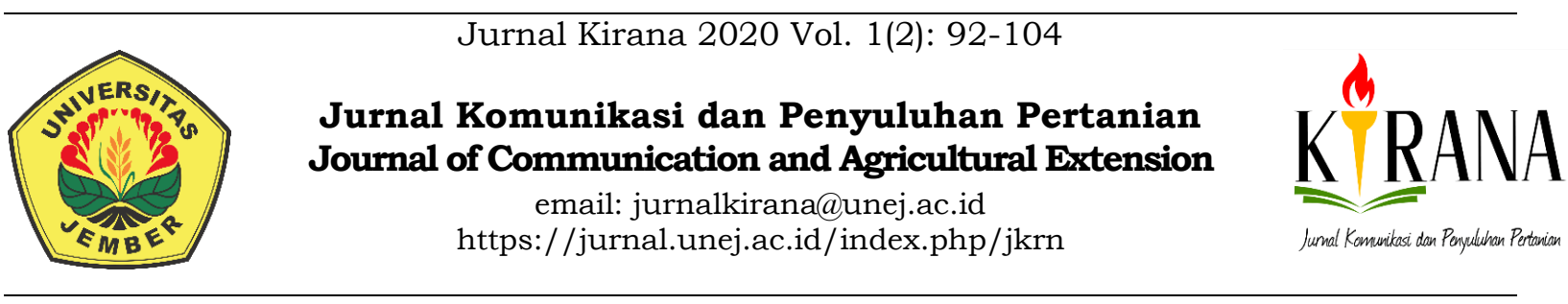

\title{
Modal Sosial Kelompok Tani Hutan Santuso II dalam Pengembangan Kapulaga di Desa Sumberpakem Kecamatan Sumberjambe Kabupaten Jember
}

\section{Social Capital of Santuso II Forest Farmer Group in Cardamom Development in Sumberpakem Village, Sumberjambe District, Jember Regency}

\section{Nadira Tri Hapsari ${ }^{1}$ dan Rokhani ${ }^{2}{ }^{凶}$}

${ }^{1}$ Program Studi Agribisnis Fakultas Pertanian Universitas Jember

2 Program Studi Penyuluhan Pertanian Fakultas Pertanian Universitas Jember

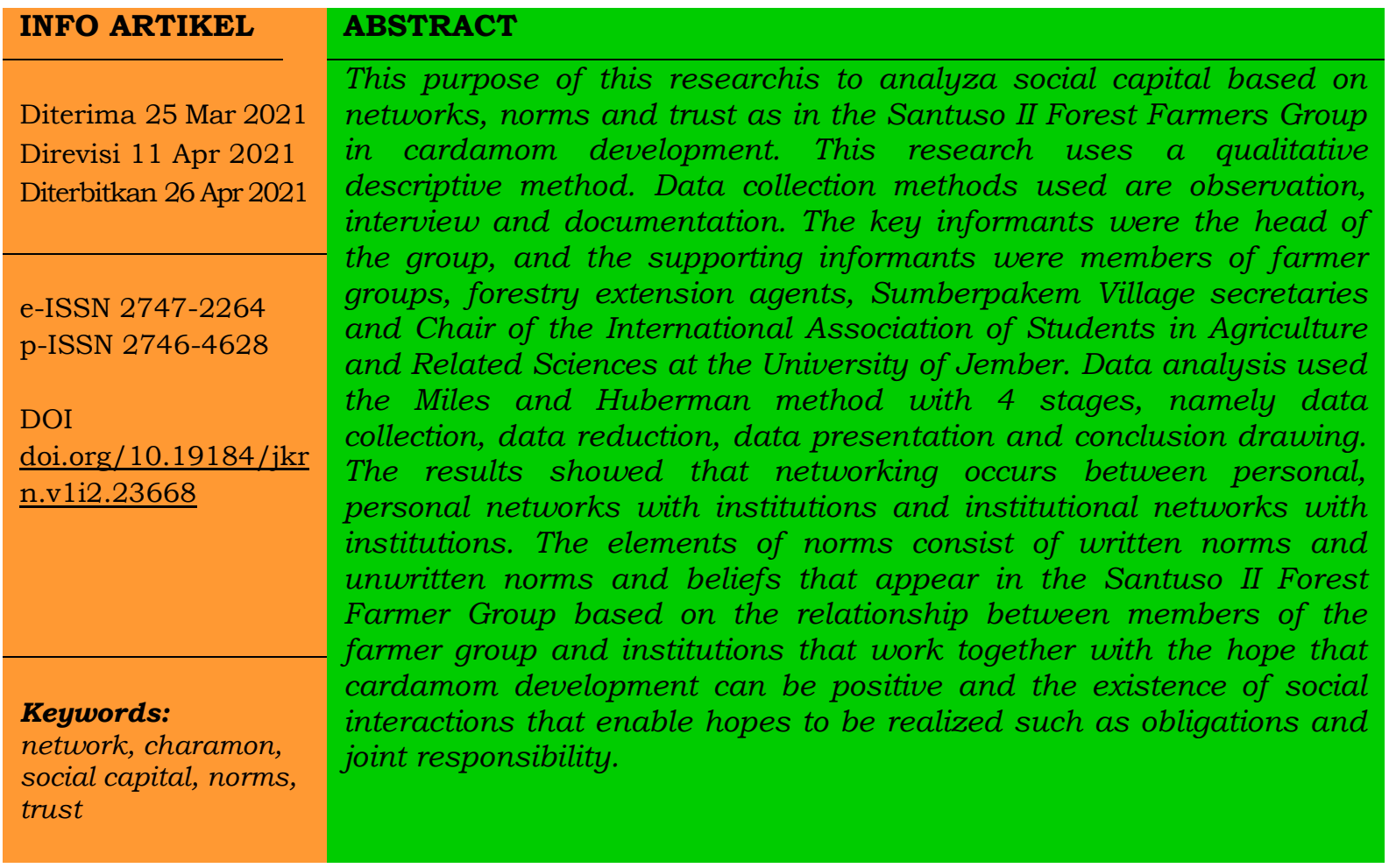

$凶$ Penulis Koresponden :

E-mail rokhani@unej.ac.id 



\begin{tabular}{|c|c|}
\hline & ABSTRAK \\
\hline & $\begin{array}{l}\text { Penelitian ini bertujuan untuk mengkaji modal sosial berdasarkan } \\
\text { jaringan, norma dan kepercayaan pada Kelompok Tani Hutan } \\
\text { Santuso II dalam pengembangan kapulaga. Penelitian ini } \\
\text { menggunakan metode deskriptif kualiatif. Metode pengumpulan data } \\
\text { yang digunakan yaitu observasi, wawancara dan dokumentasi. } \\
\text { Informan kunci adalah Ketua kelompok, dan informan pendukung } \\
\text { adalah anggota kelompok tani, penyuluh kehutanan, sekeratis Desa } \\
\text { Sumberpakem dan Ketua Internasional Association of Student in } \\
\text { Agriculture and Related Sciences Universitas Jember. Analisis data } \\
\text { menggunakan metode Miles dan Huberman dengan } 4 \text { tahapan yaitu } \\
\text { pengumpulan data, reduksi data, penyajian data dan penarikan } \\
\text { kesimpulan. Hasil penelitian menunjukkan jaringan terjadi antar } \\
\text { personal, jaringan personal dengan institusi dan jaringan institusi } \\
\text { dengan institusi. Unsur norma terdiri dari norma tertulis dan norma } \\
\text { tidak tertulis dan kepercayaan yang muncul pada Kelompok Tani }\end{array}$ \\
\hline $\begin{array}{l}\text { Kata kunci: } \\
\text { jaringan, kapulaga, } \\
\text { modal sosial, norma, } \\
\text { kepercayaan }\end{array}$ & $\begin{array}{l}\text { Hutan Santuso II didasari hubungan antara anggota kelompok tani } \\
\text { dengan institusi yang saling bekerjasama dengan harapan } \\
\text { pengembangan kapulaga dapat bernilai positif dan adanya interaksi } \\
\text { sosial yang memungkinkan harapan terwujud seperti adanya } \\
\text { kewajiban dan tanggungjawab bersama.. } \\
\text { (C) 2020, PS Penyuluhan Pertanian UNEJ }\end{array}$ \\
\hline
\end{tabular}

\section{PENDAHULUAN}

Program pembangunan yang dilakukan pemerintah yaitu penyelenggaraan pembangunan kehutanan berbasis kepada masyarakat. Menurut (Undang Undang Republik Indonesia Nomor 41 Tahun 1999 Pasal 70). masyarakat turut berperan serta dalam pembangunan di bidang kehutanan. Upaya masyarakat dalam melakukan pembangunan di bidang kehutanan salah satunya yaitu dalam pengelolaan hutan rakyat. Masyarakat sekitar hutan dalam memaksimalkan lahan hutan produksi dapat membudidayakan tanaman kayu serta tanaman non kayu secara bersamaan. Jenis tanaman non kayu yang dapat dibudidayakan yaitu tanaman rempah. Kapulaga merupakan tanaman rempah yang yang cocok dibudidayakan sebagai tanaman bawah naungan. Desa Sumberpakem Kecamatan Sumberjambe merupakan daerah yang membudidayakan kapulaga di Kabupaten Jember. Desa Sumberpakem menjadi desa pengembangan budidaya tanaman kapulaga yang didukung oleh Cabang Dinas Kehutanan Wilayah Kerja Jember. Masyarakat petani sekitar hutan dalam mempermudah pekerjaannya tergabung dalam suatu kelompok tani hutan yang diberi nama sebagai Kelompok Tani Hutan Santuso II.

Kapulaga yang dibudidayakan oleh Kelompok Tani Hutan Santuso II kemudian diolah menjadi minuman kopi herbal kapulaga. Tujuan dalam pembuatan produk olahan ini yaitu untuk memberikan nilai tambah pada kapulaga. Penelitian yang dilakukan oleh Setiawan \& Soejono, (2018) menunjukkan nilai tambah produk kopi herbal kapulaga yang dihasilkan oleh agroindustri kopi herbal kapulaga mampu memberikan nilai tambah yang positif baik bagi kopi maupun kapulaga sebagai bahan baku kopi herbal kapulaga. Nilai tambah kopi herbal kapulaga bagi kopi adalah $\mathrm{Rp} 127.523,39 / \mathrm{kg}$ dan Rp 
$681.237,67 / \mathrm{kg}$ bagi kapulaga. Hasil penelitian ini menunjukkan prospek pengembangan kopi herbal kapulaga lemah-berpeluang, dimana diperlukan penguatan kerjasama dengan lembaga atau institusi pendukung untuk mengoptimalkan kualitas bahan baku, kapasitas produksi, serta memperluas saluran pemasaran yang dimiliki.

Kegiatan yang dilakukan oleh Kelompok Tani Hutan Santuso II merupakan kegiatan agribisnis dari hulu hingga hilir yang artinya berkaitan satu sama lain dalam pengembangan kapulaga, dimana jika salah satu subsistem gagal maka akan berdampak pada subsistem lainnya. Modal sosial diperlukan dalam kelompok untuk dapat memudahkan dalam mencapai tujuan pengembangan kapulaga oleh kelompok. Modal sosial sebagai sumberdaya yang muncul dari adanya relasi sosial dan dapat digunakan untuk menjaga kesatuan anggota kelompok dalam mencapai tujuan bersama, ditopang dengan adanya kepercayaan dan norma sebagai acuan bersikap, bertindak dan berhubungan satu sama lain. Kegiatan hulu hingga hilir pengembangan kapulaga yang dilakukan oleh Kelompok Tani Hutan Santuso II dapat berlangsung karena didukung oleh faktor-faktor sosial seperti kerjasama atau gotong royong, pengakuan terhadap anggota masyarakat atas kepemilikan lahan yang dimiliki oleh individu, rasa saling percaya satu dengan yang lain dalam mengelola hutan, serta adanya jaringan untuk memperoleh bibit kapulaga dan pemasaran kapulaga. Kelompok Tani Hutan Santuso II merupakan kelompok tani yang sudah berbadan hukum, sehingga Kelompok Tani Hutan Santuso II juga telah memiliki AD/ART sebagai salah satu syarat bagi kelompok tani untuk mengajukan badan hukum. AD/ART yang dimiliki Kelompok Tani Hutan Santuso II digunakan sebagai pedoman dasar dalam melakukan kegiatan usahatani.

\section{METODE PENELITIAN}

Lokasi pada penelitian ini adalah di Desa Sumberpakem Kecamatan Sumberjambe Kabupaten Jember dengan pertimbangan bahwa: (1) Desa Sumberpakem merupakan daerah pengembangan kegiatan pertanian masyarakat kehutanan terkait kapulaga sejak tahun 2015, di 3 dusun yang membudidayakan kapulaga yaitu Karang Duren, Karang Tengah dan Pandian, (2) Memiliki Kelompok Tani Hutan Non Pangan kelas madya satu-satunya di Kecamatan Sumberjambe yang mengembangkan tanaman kapulaga dengan nama Kelompok Tani Hutan Santuso II.

Penelitian menggunakan metode deskriptif kualitatif dilakukan dengan wawancara kepada informan, hasil wawancara tersebut disusun menjadi teks naratif yang menjawab permasalahan pada penelitian ini. Data primer diperoleh dari informan. Informan kunci adalah Ketua Kelompok Tani Hutan Santuso II dan untuk menentukkan informan selanjutnya menggunakan purposive sampling. Beberapa kriteria yang menjadi pertimbangan dalam pemilihan informan adalah: (1) mereka yang menguasai atau memahami sesuatu melalui proses enkultrasi, sehingga sesuatu itu bukan sekedar diketahui, tetapi juga dikhayati, (2) mereka yang tergolong masih berkecimpung atau terlibat pada kegiatan yang tengah diteliti, (3) mereka yang mempunyai waktu yang memadai untuk dimintai informasi, (4) mereka yang tidak cenderung menyampaikan informasi hasil "kemasannya" sendiri, (5) mereka yang pada mulanya tergolong "cukup asing" dengan penelitian sehingga lebih menggairahkan untuk dijadikan semacam guru atau narasumber. 
Pengumpulan data primer menggunakan wawancara mendalam dan observasi partisipan pasif. Pengumpulan data sekunder diperoleh dari dokumentasi. Dokumentasi data sekunder yang digunakan adalah: (1) dokumen yang ada di kelompok tani hutan; (2) dokumen dari Cabang Dinas Kehutanan Wilayah Kerja Jember; (3) dokumen dari Badan Pusat Statistik Tanaman Biofarmaka Indonesia; (4) dokumen dari Badan Pusat Statistik Kabupaten Jember. (Miles \& Huberman, 1992), mengemukakan bahwa aktivitas dalam analisis data kualitatif digunakan secara interaktif dan berlangsung secara terus menerus sampai tuntas, sehingga datanya sudah jenuh. Aktivitas dalam analisis data yaitu pengumpulan data, reduksi data, penyajian data dan penarikan kesimpulan.

\section{HASIL DAN PEMBAHASAN}

Modal sosial merupakan pondasi dasar komunitas yang komponennya meliputi jaringan sosial, norma dan kepercayaan yang mendorong partisipan bertindak bersama secara lebih efektif untuk mencapai tujuan-tujuan bersama (Putnam, 1995). Keberadaan modal sosial menjadi penting dalam masyarakat sebagai strategi dan perkembangannya ketika telah disadari peran dan fungsinya. Penelitian ini dilakukan untuk mengetahui modal sosial pada Kelompok Tani Hutan Santuso II dalam pengembangan kapulaga di Desa Sumberpakem. Terdapat tiga unsur modal sosial yang pertama jaringan pada interaksi antar kelompok dan pihak-pihak yang terkait dengan pengembangan kapulaga. Kedua, keberadaan norma-norma yang terdapat pada Kelompok Tani Hutan Santuso II dan ketiga, kepercayan yang terjalin antar anggota kelompok dengan pihak-pihak yang terkait dengan pengembangan kapulaga di Desa Sumberpakem.

\section{Jaringan pada Kelompok Tani Hutan Santuso II dalam Pengembangan Kapulaga}

Jaringan sebagai pola pertukaran informasi dan interaksi sosial yang terus berkembang merupakan perwujudan penting dari modal sosial. Menurut Lawang, (2004), jaringan adalah ikatan atau simpul (orang atau kelompok) yang dihubungkan dengan media (hubungan sosial). Terdapat beberapa bentuk dari jaringan yaitu; 1) Jaringan antar personal; 2) Jaringan antar individu dan institusi dan 3) Jaringan antar institusi. Jaringan tersebut terbentuk karena adanya interaksi yang dilakukan.

1. Jaringan antar personal

Jaringan antar personal dapat dilihat melalui jumlah orang yang terlibat didalamnua, ada beberapa bentuk jaringan yang dapat diidentifikasi.

a. Jaringan (dydac) tunggal merujuk pada jaringan yang terbentuk anatara dua orang saja, tanpa ada jaringan lainnya. Jika terdapat suatau permasalahan maka akan cenderung bekerjasama dengan orang yang itu-itu saja. Pada Kelompok Tani Hutan Santuso II jaringan duaan terjadi karena adanya interaksi antara sesama anggota kelompok tani. Berikut merupakan gambar dari hubungan sesama anggota kelompok tani.

$$
\text { Anggota A Anggota B }
$$

\section{Gambar 1. Pola Interaksi Sesama Anggota Kelompok Tani}


Berdasarkan Gambar 1 pola tersebut membentuk struktur yang paling sederhana. Garis yang menghubungkan titik atau simpul mencerminkan pola interaksi yang terjadi diantara keduanya. Interaksi tersebut terjadi karena anggota kelompok tani saling bertemu dan bertukaran informasi hal ini juga disebabkan karena rumah antar anggota kelompok tani yang berdekatan sehingga memungkinkan interaksi terjadi setiap hari. Kondisi rumah yang saling berdekatan juga membuat sesama anggota kelompok tani sering bekerjasama dalam melakukan kegiatan sehari-hari. Sesama anggota kelompok tani juga saling berbagi mengenai informasi budidaya kapulaga.

Pertukaran informasi yang diberikan mengenai cara budidaya kapulaga, perawatan, proses pasca panen hingga pemasaran kapulaga. Sesama anggota kelompok tani tidak merasa tersaingi dengan petani lain yang juga membudidayakan kapulaga. Petani yang ingin membudidayakan kapulaga mendapat dukungan dari petani lain dengan cara memberikan bibit kapulaga secara gratis untuk dikembangkan, hal ini tidak mengakibatkan petani kehilangan tempat untuk memasarkan kapulaga. Petani memiliki keyakinan dengan semakin banyak yang membudidayakan kapulaga akan mempermudah dalam pemasaran kapulaga. Kondisi tersebut terjadi karena kapulaga hanya dapat dipasarkan dipasar-pasar tertentu dengan jumlah permintaan yang besar, sedangkan kapulaga hanya sebagai tanaman bawah naungan pohon sengon sehingga hasil yang diperoleh setiap petani tidak cukup untuk memenuhi kebutuhan pasar jika ingin dijual secara individu. Bergabungnya petani dengan mengikuti Kelompok Tani Hutan Santuso II memberikan akses dalam memasarkan hasil panen kapulaga yang dibudidayakannya. Kelompok Tani Hutan Santuso II sebagai wadah bagi petani dalam menjual hasil panen kapulaga, sehingga jika kapulaga milik petani dibeli oleh kelompok maka akan mempermudahkan petani dalam memasarkan hasil usahataninya.

Selain interaksi anggota dengan anggota terdapat pula interaksi antara sesama pengurus dalam kelompok tani. Interaksi tersebut terjadi karena adanya pertemuan rutin yang diadakan oleh pengurus Kelompok Tani Hutan Santuso II setiap 2 minggu sekali, kegiatan rutin yang dilaksanakan atas dasar silaturahmi. Pertemuan rutin tersebut membahas mengenai agenda kelompok tani. Pertemuan kelompok tani dilaksanakan secara rutin setiap 2 minggu sekali, apabila diperlukan pertemuan kelompok tani dapat dilaksanakan diluar jadwal pertemuan rutin

\section{b. Jaringan ganda}

Jaringan ganda pada Kelompok Tani Hutan Santuso II terjadi karena adanya kepentingan yang saling menguntungkan antara sesama anggota kelompok tani. Pola interaksi mengenai hubungan sesama anggota kelompok tani disajikan pada Gambar 2.

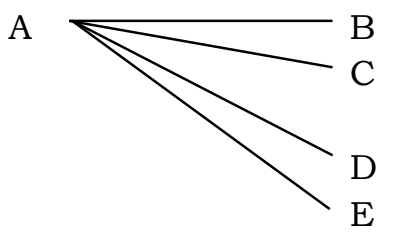

Gambar 2. Pola interaksi Kelompok Tani Hutan Santuso II 


\author{
Keterangan: \\ A: Ketua Kelompok Tani Hutan Santuso II \\ B: Anggota 1 \\ C: Anggota 2 \\ D: Anggota 3 \\ E: Anggota 4
}

Interaksi pada jaringan duaan ganda yang terjadi pada Kelompok Tani Hutan Santuso II dapat digambarkan dengan simpul atau titik A, B, C, D, E. Interaksi tersebut terjadi karena masing-masing anggota kelompok membudidayakan kapulaga secara individu dengan bibit kapulaga berasal dari kelompok. Anggota kelompok tani menjual hasil panen kapulaga kepada kelompok tani. Kemudian oleh ketua kelompok, kapulaga yang telah dibeli dari anggota diolah menjadi minuman kopi herbal kapulaga. Kegiatan jual-beli kapulaga tersebut saling memberikan keuntungan bagi ketua maupun anggota kelompok tani, dimana anggota kelompok tidak kesulitan dalam memasarkan hasil panen kapulaganya sedangkan ketua kelompok tani dimudahkan memperoleh bahan baku pembuatan produk kopi herbal kapulaga yang bahan-bahannya diperoleh dari anggota kelompok taninya sendiri.

Olahan kapulaga yang diolah oleh ketua Kelompok Tani Hutan Santuso II kemudian dipasarkan pada Usaha Mikro Kecil Menengah (UMKM) Santuso Barokah" yang didirikannya. UMKM didirikan dengan tujuan untuk menampung produk-produk olahan yang dimiliki oleh anggota kelompok tani. Adanya Usaha Mikro Kecil Menengah (UMKM) Santuso Barokah yang dimiliki oleh Kelompok Tani Hutan Santuso II memberikan lapangan pekerjaan bagi masyarakat Desa Sumberpakem khususnya yang terdapat di Dusun Karang Tengah. UMKM Santuso Barokah memiliki 4 tenaga kerja yang berasal dari keluarga dan tetangga di Desa Sumberpakem, hal ini memberikan dampak bagi masyarakat Desa Sumberpakem. Empat tenaga kerja yang seluruhnya perempuan dan merupakan seorang ibu-ibu dipilih karena perempuan dianggap memiliki keuletan dalam bekerja menurut ketua Kelompok Tani Hutan Santuso II. UMKM Santuso Barokah membentuk interaksi sesama angggota kelompok tani dengan saling bekerjasama dalam memproduksi produk kopi herbal kapulaga yang diproduksi oleh Kelompok Tani Hutan Santuso II. Kerjasama yang terjalin mengembangkan sikap dan tindakan saling menguntungkan satu sama lain. Masyarakat Desa Sumberpakem diuntungkan karena memperoleh pekerjaan di UMKM Santuso Barokah. Tenaga kerja yang bekerja tidak perlu disibukkan untuk berbelanja bahan baku yang harus diolah, karena bahan baku pembuatan produk kopi herbal kapulaga sudah tersedia dan dipenuhi oleh anggota Kelompok Tani Hutan Santuso II seperti kapulaga, jahe dan kayu manis. Sementara itu, anggota kelompok tani juga diuntungkan, karena mereka tidak perlu susah payah menjual hasil panennya. Adanya keuntungan inilah yang mendorong anggota kelompok tani untuk melanjutkan interaksi dan aktif dalam kegiatan kelompok. Adanya interaksi tersebut membentuk jaringaan duaan ganda. Jaringan ini pada dasarnya bersifat duaan, sehingga kecendrungan yang terjadi pada hubungan duaan dapat terjadi pula pada jaringan ini. 
2. Jaringan individu dengan kelompok

Jaringan individu dengan kelompok dapat terjalin karena adanya interaksi yang dilakukan, interaksi tersebut berupa interaksi anggota dengan pengurus. Interaksi anggota dengan pengurus terjalin karena adanya kegiatan pertemuan kelompok. Pertemuan kelompok diadakan secara rutin setiap 1 bulan sekali, dalam pertemuan tersebut terdapat kegiatan penyuluhan maupun pembinaan. Penyuluhan yang pernah diadakan yaitu penyuluhan "Bimbingan Teknis budidaya tanaman kapulaga sebagai pengembangan hasil hutan non kayu" dan penyuluhan mengenai "Temu Teknologi Kehutanan KTH Santuso II Tentang Budidaya Tanaman Kapulaga dan Pengolahan Hasil Kopi Herbal Kapulaga." Pertemuan yang diadakan secara rutin setiap satu bulan sekali terutama membahas mengenai pengembangan kapulaga sebagai tanaman unggulan di Desa Sumberpakem yang masih didominasi oleh penyuluh kehutanan yang berperan sebagai pendamping dari Kelompok Tani Hutan Santuso II. Peretemuan rutin tersebut tidak hanya diisi dengan pertukaran informasi, tetapi penyuluh kehutanan juga secara aktif meninjau tanaman-tanaman kapulaga yang dibudidayakan oleh anggota kelompok tani. Kegiatan tersebut membuat anggota secara aktif menanyakan hal-hal mengenai permasalahan kapulaga atau kegiatan usahatani yang dihadapinya, sehingga tercipta keakraban yang terjalin antara anggota dengan penyuluh kehutanan.

Keterlibatan penyuluh kehutanan sebagai pendamping bagi Kelompok Tani Hutan Santuso II membentuk pola hubungan kerjasama yang dilakukan. Penyuluh kehutanan sebagai pendamping dari kelompok tani bertugas memberikan informasi melalui kegiatan penyuluhan dan sosialisasi pada Kelompok Tani Hutan Santuso II. Adanya penyuluhan yang dilakukan oleh penyuluh kehutanan memberikan tambahan informasi bagi petani-petani yang tergabung dalam kelompok tani dalam pengembangan kapulaga. Penyuluhan yang dilakukan tidak hanya mengenai kapulaga, tetapi juga disesuaikan dengan musim tanam yang dilakukan oleh petani.

3. Jaringan antar institusi

Institusi yang menjalin interaksi dengan Kelompok Tani Hutan Santuso II yaitu Cabang Dinas Kehutanan Wilayah Kerja Jember, Pemerintah Desa Sumberpakem, Internasional Association of Student in Agriculture and Related Sciences (IAAS) Universitas Jember. Interaksi tersebut karena adanya kerjasama yang dilakukan. Kerjasama tersebut berupa kegiatan pembinaan bagi anggota kelompok tani dalam kegiatan pengembangan kapulaga.

a. Pemerintah Desa Sumberpakem

Pemerintah Desa Sumberpakem merupakan pelindung dari berdirinya Kelompok Tani Hutan Santuso II. Kondisi tersebut menjadikan adanya interaksi yang terjalin. Interaksi yang terjalin ditunjukkan dengan peran Pemerintah Desa Sumberpakem sebagai pelindung dari kelompok tani yang memberikan ijin atas setiap kegiatan yang dilakukan oleh kelompok. Selain itu, Pemerintah Desa Sumberpakem juga memberikan bantuan-bantuan seperti fasilitas pembinaan mengenai pengembangan komoditas unggulan di Desa Sumberpakem yaitu kapulaga. Pemerintah Desa Sumberpakem memberikan kemudahan bagi Kelompok Tani Hutan Santuso II dalam pembuatan perijinan kegiatan yang dilakukan oleh kelompok tani. Interaksi tersebut memberikan 
keuntungan bagi Kelompok Tani Hutan Santuso II karena kemudahan untuk mengakses sumberdaya yang berasal dari luar kelompok yang nantinya digunakan untuk kepentingan kelompok secara bersama-sama.

b. Cabang Dinas Kehutanan (CDK) Wilayah Kerja Jember

Peran dan tanggungjawab Cabang Dinas Kehutanan Wilayah Kerja Jember adalah memberikan bimbingan teknis mengenai pengelolaan budidaya tanaman kapulaga dan pengolahan hasil kopi herbal kapulaga oleh penyuluh kehutanan. Penyuluhan tersebut dilakukan mulai dari hulu hingga hilir penanganan pasca panen kapulaga. Penyuluhan diikuti oleh anggota Kelompok Tani dan dibimbing oleh penyuluh kehutanan. Cabang Dinas Kehutanan Wilayah Kerja Jember juga memberikan bantuan bibit kapulaga secara gratis kepada Kelompok Tani Hutan Santuso II.

Penyuluh kehutanan yang ada di Kelompok Tani Hutan Santuso II merupakan pendamping dari kelompok tani. Penyuluh kehutanan ditugaskan oleh Cabang Dinas Kehutanan Wilayah Kerja Jember sebagai pendamping petani di Desa Sumberpakem. Tugas dari seorang penyuluh kehutanan yaitu memberikan pembinaan kepada petani-petani khususnya yang berada di Desa Sumberpakem. Penyuluh Kehutanan yang saat ini menjadi pendamping dari kelompok tani sudah menjadi penyuluh sejak sebelum kelompok tani ini ditetapkan menjadi Kelompok Tani Hutan non pangan.

Penyuluh kehutanan berperan sebagai fasilitas dalam mengatasi permasalahan yang dihadapi oleh petani di Desa Sumberpakem. Adanya penyuluh kehutanan memfasilitasi petani dalam Kelompok Tani Hutan Santuso II untuk meningkatkan hasil budidaya kapulaga mulai dari pengelolaan, pengemasan hingga pemasaran kapulaga. Peran tersebut ditunjukkan dengan kegiatan penyuluhan yang diadakan oleh penyuluh setiap satu bulan sekali. Penyuluhan tersebut biasanya berkaitan dengan cara budidaya kapulaga, perawatan, pemanenan hingga pengecekan lahan kapulaga yang dimiliki oleh Kelompok Tani Hutan Santuso II. Penyuluh kehutanan memiliki peranan penting bagi kelompok tani, dikarenakan dengan informasi yang diberikannya bersumber dari dua arah yaitu informasi dari Kelompok Tani Hutan Santuso II ke Cabang Dinas Kehutanan Jember begitu juga sebaliknya. Sehingga penyuluh kehutanan berperan dalam menjembatani hubungan antar kedua institusi tersebut.

c. Internasional Association of Student in Agriculture and Related Sciences (IAAS) Universitas Jember

Kegiatan IAAS Universitas Jember salah satunya yaitu Village Concept Project (VCP) yang merupakan proyek konsep desa yang bertujuan untuk meningkatkan standar hidup masyarakat pedesaan sektor pertanian dan lingkungan, serta pendidikan dan pemberdayaan masyarakat. Kegiatan VCP yaitu memiliki Desa Binaan, pada IAAS Universitas Jember desa yang menjadi binaan tersebut berada di Desa Sumberpakem. Kegiatan yang dilakukan untuk desa binaan di Desa Sumberpakem yaitu dilakukan di Kelompok Tani Hutan Santuso II. Peran IAAS Universitas Jember dalam mendampingi masyarakat di Desa Sumberpakem dan memfasilitasi Kelompok Tani Hutan Santuso II dalam setiap tahap proses pembuatan Produk Industri Rumah Tangga (PIRT) sejak persiapan awal untuk memperoleh sertifikat produksi pangan, melengkapi persyaratan yang dibutuhkan 
dan berupaya untuk mempermudah pemasaran produk kopi herbal kapulaga. Pengajuan pembuatan PIRT untuk produk kopi herbal kapulaga yang dibantu IAAS Universitas Jember dalam pengurusan administrasinya telah dilakukan sejak bulan oktober 2019 dan sampai saat ini masih dalam proses verifikasi.

Produk Industri Rumah Tangga atau yang disebut PIRT merupakan izin produksi pangan yang dihasilkan skala industri rumah tangga yang ditetapkan oleh BPOM (Badan Pengawasan Obat dan Makanan). PIRT memiliki fungsi sebagai izin edar suatu produk pangan, dimana produk tersebut dapat secara legal diedarkan atau dipasarkan baik dengan cara dititipkan atau dijual langsung kepada masyarakat luas. UMKM yang telah memiliki PIRT dapat mengedarkan produknya dengan jalur distribusi yang lebih luas, khususnya jika ingin menitipkan produknya di toko-toko modern yang sudah terkenal dan memiliki basis konsumen tetap seperti toko oleh-oleh. Produk kopi herbal kapulaga yang telah memiliki PIRT akan mempermudah dalam pemasaran produk. Saat ini produk kopi herbal kapulaga yang diproduksi oleh Kelompok Tani Hutan Santuso II hanya dipasarkan secara offline. Kelompok Tani Hutan Santuso II dalam memproduksi kopi herbal kapulaga khususnya dalam segi pemasaran tidak bekerjasama dengan institusi lain sehingga pemasaran produk kopi herbal kapulaga cenderung lambat. Kegiatan promosi yang dilakukan hanya pada saat mengikuti pameran-pameran saja, dengan pasifnya kegiatan promosi mengakibatkan produk kopi herbal kapulaga kurang dapat menarik minat calon konsumen.

Kelompok Tani Hutan Santuso II memiliki jaringan dengan 3 institusi yaitu Pemerintah Desa Sumberpakem, Cabang Dinas Kehutanan Wilayah Kerja Jember dan Internasional Association of Student in Agriculture and Related Sciences (IAAS) Universitas Jember. Menurut Bourdieu dalam Usman, (2018), jumlah modal sosial yang dimiliki aktor-aktor bergantung pada ukuran jejaring koneksi yang dapat mereka gerakkan secara efektif. Jumlah modal sosial tersebut lebih ditentukan oleh seberapa luas relasi-relasi sosial yang mampu mereka kembangkan. Semakin luas relasi-relasi sosial yang mampu dikembangkan maka semakin besar jumlah modal sosial yang dimiliki. Jaringan eksternal yang dimiliki oleh Kelompok Tani Hutan Santuso II memberikan manfaat bagi kelompok. Jaringan tersebut memberikan akses kemudahan bagi anggota kelompok tani dalam memperoleh sumberdaya dari luar kelompok yang kemudian mereka gunakan untuk mendapatkan keuntungan.

\section{Norma pada Kelompok Tani Hutan Santuso II dalam Pengembangan Kapulaga}

Adanya jaringan yang terbentuk pada Kelompok Tani Hutan Santuso II menimbulkan interaksi dan transaksi yang selanjutnya mendorong mereka mengembangkan norma-norma yang memfasilitasi kerjasama yang saling menguntungkan dengan pihak yang terkait. norma yang terdapat pada Kelompok Tani Hutan Santuso II yaitu norma tertulis dan norma tidak tertulis yang menjadi pedoman dalam melaksanakan kegiatan yang ada pada kelompok tani khususnya dalam pengembangan kapulaga. 
1. Norma tertulis Kelompok Tani Hutan Santuso II

a. Anggaran Dasar dan Anggaran Rumah Tangga (AD/ART) Kelompok Tani Hutan Santuso II

Kelompok Tani Hutan Santuso II memiliki AD/ART sebagai pedoman untuk pelaksanaan tugas masing-masing pengurus dan anggotanya sehingga pembagian tugas dalam kelompok menjadi jelas dan teratur. Kelompok Tani Hutan Santuso II berdiri atas kesepakatan beberapa orang yang memiliki tujuan yang sama yaitu untuk kesejahteraan petani. Setiap ketentuan dalam AD/ART harus dapat dimengerti dan dilaksanakan oleh para anggota, pengurus, pendamping dan pelindung dalam pengelolaan Kelompok Tani Hutan Santuso II, karena AD/ART memiliki kedudukan yang mengatur keseluruhan kegiatan dalam kelompok tani. Adanya AD/ART sebagai norma tertulis yang dimiliki kelompok tani diharapkan semua pihak yang terlibat berperan serta dalam mempertanggungjawabkan isi AD/ART yang ada pada kelompok tani. Isi yang terdapat dalam AD/ART disesuaikan dengan tujuan dan kepentingan anggota Kelompok Tani Hutan Santuso II dengan memperhatikan kondisi dan kebutuhan bagi kepentingan anggota kelompok tani.

b. Surat Perjanjian Kerjasama (SPKS)

Surat perjanjian kerjasama antara Kelompok Tani Hutan Santuso II dengan Cabang Dinas Kehutanan (CDK) Wilayah Kerja Jember. Surat perjanjian kerjasama ini berisikan kesepakatan-kesepakatan antara kedua belah pihak mengenai bantuan yang diberikan oleh CDK Jember untuk kelompok tani. Kesepakatan tersebut diantaranya mengenai pembuatan Laporan Pertanggungjawaban (LPJ) mengenai alokasi penerimaan bantuan yang diberikan. Laporan pertanggungjawaban ini dilaporkan setelah penerimaan bantuan diberikan selambat-lambatnya sebulan setalah bantuan diterima. Bantuan yang diberikan tidak hanya berupa bantuan finansial saja tetapi terdapat bantuan berupa bibit, alat-alat pertanian hingga pembinaan. Apabila dalam laporan pertanggungjawaban yang telah dibuat oleh kelompok dalam penggunaan bantuan tidak sesuai maka kelompok berkewajiban untuk mengganti, hal tersebut merupakan sanksi yang harus diterima oleh kelompok tani. Sanksi tersebut diberikan apabila terdapat penyalahgunaan bantuan secara finansial misalnya digunakan untuk keperluan pribadi, maka yang bertanggungjawab adalah ketua kelompok tani. Tetapi, jika bantuan seperti bibit tidak tepat sasaran maka pihak pemberi bantuan yaitu CDK Jember memberikan toleransi kepada kelompok tani.

2. Norma Tidak Tertulis pada Kelompok Tani Hutan Santuso II dalam pengembangan kapulaga

Kelompok Tani Hutan Santuso II mempunyai norma atau aturan tidak tertulis yang telah disepakati oleh anggota. Umumnya, aturan tersebut hanya berupa kesepakatan tidak tertulis yang sudah biasa dilakukan oleh anggota kelompok tani. Anggota Kelompok Tani Hutan Santuso II umumnya melaksanakan dan mematuhi norma yang telah disepakati berdasarkan kesadaran diri. Secara rinci aturan-aturan yang telah disepakati yaitu, meliputi: (a) kesepakatan setiap anggota menjual kapulaga kering kepada Kelompok Tani Hutan Santuso II; (b) melaporkan penjualan kapulaga kepada 
Kelompok Tani Hutan Santuso II; (c) kesepakatan-kesepakatan tersebut jika dilanggar oleh anggota, anggota diberi sanksi berupa teguran. Aturan-aturan tersebut pada dasarnya merupakan kebiasaan atau tradisi yang sudah dilaksanakan oleh Kelompok Tani Hutan Santuso II.

\section{Kepercayaan pada Kelompok Tani Hutan Santuso II dalam Pengembangan Kapulaga}

Kepercayaan merupakan hal yang kompleks dalam lingkungan yang modern dari dua sumber yang mengikat yaitu norma dan jaringan. Adanya rasa saling mempercayai dapat memudahkan dalam menjalin suatu kerjasama. Semakin besar rasa percaya maka akan terbangun pula kerjasama yang kuat. Kepercayaan adalah pengharapan yang muncul dalam sebuah komunitas yang berperilaku normal, jujur, dan kooperatif berdasarkan norma-norma yang dimiliki bersama dengan kepentingan anggota yang lain (Fukuyama, 2010).

Menurut Lawang, (2004), kondisi saling percaya yang terjalin selama ini ditunjang oleh beberapa hal diantaranya melalui:

a. Hubungan Sosial antara Dua Orang atau Lebih

Hubungan yang terjalin menunjukkan terdapat kepentingan bersama diantara anggota kelompok yang menyatukan mereka dalam suatu kelompok tani. Berdasarkan hasil penelitian yang telah dilakukan diketahui adanya hubungan yang dimiliki Kelompok Tani Hutan Santuso II karena adanya kerjasama yang dilakukan dengan instansi diluar kelompok tani. Kerjasama tersebut memberikan kemudahan dalam mengakses bantuan-bantuan yang diberikan oleh Cabang Dinas Kehutanan Wilayah Kerja Jember dan IAAS Universitas Jember. Terdapat faktor lain yang menjadi pengikat munculnya rasa saling percaya diantara anggota kelompok, yaitu hubungan kekerabatan diantara anggota kelompok tani, sehingga anggota kelompok tani akan bekerjasama dalam mencapai tujuan bersama yaitu pengembangan kapulaga di Desa Sumberpakem. Anggota kelompok tani juga mempercayai dengan membudidayakan kapulaga akan memberikan penghasilan tambahan.

b. Harapan yang Terkandung dalam Suatu Hubungan

Menurut Lawang, (2004), harapan yang terkandung dalam hubungan jika direalisasikan tidak akan merugikan salah satu atau kedua belah pihak. Hubungan antara dua belah pihak atau lebih yang mengandung harapan yang menguntungkan salah satu atau kedua belah pihak melalui interaksi sosial. Semakin kuat dan baik hubungan sosial, semakin tinggi harapan yang ingin diperoleh. Budidaya hingga pengolahan kapulaga menjadi kopi herbal kapulaga diharapkan dapat memberikan dan memperluas lapangan pekerjaan bagi masyarakat yang berada di Desa Sumberpakem. Pengembangan kapulaga yang dilakukan oleh Kelompok Tani Hutan Santuso II diharapkan akan memberikan dampak baik bagi Desa Sumberpakem sebagai produk unggulan yang ada di desa Sumberpakem.

c. Interaksi sosial yang memungkinkan hubungan dan harapan terwujud

Modal sosial merupakan hasil dari tumbuh dan berkembangnya organisasi ditengah-tengah masyarakat yang saling percaya dan merupakan sebuah institusi yang dekat dengan masyarakat (Regaty, 2017). Kepentingan dalam penjualan kapulaga pada kelompok beriorientasi kepada kemudahan akses pasar kapulaga dalam jumlah yang lebih banyak jika dibandingkan dijual secara individu. Adanya faktor inilah yang menjadi pengikat munculnya 
rasa saling percaya diantara Kelompok Tani Hutan Santuso II, sehingga dengan bekerja secara bersama akan mencapai tujuan bersama. Selain kepercayaan yang berasal dari internal kelompok, kepercayaan juga dapat tercapai dengan adanya institusi formal. Cabang Dinas Kehutanan Wilayah Kerja Jember dan Pemerintah Desa Sumberpakem sebagai lembaga formal yang sekaligus menjadi pendamping dan pelindung bagi Kelompok Tani Hutan Santuso II juga memberikan bantuan untuk kelompok.

Kelompok Tani Hutan Santuso II diwajibkan untuk membuat LPJ (Laporan Pertanggungjawaban). Adanya LPJ sebagai aturan tersebut membuat Kelompok Tani Hutan Santuso II dipercaya dalam pengalokasian bantuan yang diberikan. Kepercayaan yang terjalin terlihat dari pemahaman anggota kelompok akan sanksi yang akan diterima apabila melanggar aturan tersebut. Hal ini membuktikan bahwa Kelompok Tani Hutan Santuso II memegang teguh aturan yang berlaku. Adanya aturan tersebut sebagai pedoman dalam bertindak sehingga terjalin rasa kepercayaan antar pemberi bantuan dan penerima bantuan. Sejalan dengan teori yang dikemukakan oleh bahwa modal sosial memerlukan kewajiban dan tanggungjawab bersama untuk bertindak. Pembuatan laporan pertanggung jawaban (LPJ) bagi kelompok tani sebagai norma tertulis bagi kelompok tani mencerminkan bahwa terdapat kewajiban dan tanggungjawab yang harus dilakukan. Kepercayaan antar anggota kelompok tani, serta kelompok tani dengan pemerintah dan pihak yang terlibat dapat dilihat pada tabel dibawah sesuai dengan hal penunjang sikap saling percaya yang dialami. Selengkapnya akan tersaji pada table 1:

Tabel 1. Kepercayaan pada Kelompok Tani Hutan Santuso II dalam Pengembangan Kapulaga

\begin{tabular}{|c|c|c|c|c|}
\hline No & Kepercayaan & $\begin{array}{l}\text { Hubungan sosial } \\
\text { antara dua orang } \\
\text { atau lebih }\end{array}$ & $\begin{array}{c}\text { Harapan yang } \\
\text { akan terkandung } \\
\text { dalam suat } \\
\text { hubungan }\end{array}$ & $\begin{array}{c}\text { Interaksi sosial } \\
\text { yang } \\
\text { memungkinkan } \\
\text { harapan terwujud }\end{array}$ \\
\hline 1 & Saling percaya & $\begin{array}{l}\text { 1. Hubungan kerja } \\
\text { sama dengan } \\
\text { institusi diluar } \\
\text { kelompok tani } \\
\text { 2. Hubungan } \\
\text { kekerabatan antar } \\
\text { anggota kelompok } \\
\text { tani }\end{array}$ & $\begin{array}{l}\text { 1. Harga jual } \\
\text { kapulaga yang } \\
\text { tinggi } \\
\text { 2. Memberikan } \\
\text { lapangan } \\
\text { pekerjaan bagi } \\
\text { masyarakat sekitar } \\
\text { 3. Memberikan } \\
\text { pendapatan } \\
\text { tambahan } \\
\text { 4. Dampak positif } \\
\text { dari budi daya } \\
\text { kapulaga bagi } \\
\text { Desa } \\
\text { Sumberpakem }\end{array}$ & $\begin{array}{l}\text { 1. Adanya } \\
\text { kewajiban dan } \\
\text { tanggungjawab } \\
\text { bersama untuk } \\
\text { bertindak dalam } \\
\text { pengembangan } \\
\text { kapulaga }\end{array}$ \\
\hline
\end{tabular}

\section{KESIMPULAN}

Modal sosial pada Kelompok Tani Hutan Santuso II dalam pengembangan kapulaga di Desa Sumberpakem Kecamatan Sumberjambe Kabupaten Jember terdiri dari unsur jaringan, norma dan kepercayaan yang memfasilitasi adanya tindakan terkoordinasi dengan adanya interaksi untuk mencapai tujuan bersama. Interaksi tersebut merupakan bentuk jaringan yang 
terdapat dalam kelompok tani terdiri dari interaksi personal sesama anggota kelompok tani, anggota dengan pengurus serta sesama pengurus kelompok tani. Interaksi antara anggota dengan pengurus terwujud dalam aktivitas kelompok berupa pertemuan rutin yang diadakan setiap satu bulan sekali. Interaksi lainnya yaitu interaksi antar institusi yaitu penyuluh kehutanan, Cabang Dinas Kehutanan Wilayah Kerja Jember dan IAAS Univeritas Jember. Interaksi terjalin dalam pertemuan kelompok, penyuluhan, pembinaan dan pemberian bantuan kepada kelompok tani.

Norma pada kelompok tani berupa norma tertulis dan norma tidak tertulis. Norma tertulis yang dimiliki kelompok terdapat Anggaran Dasar dan Anggaran Rumah Tangga (AD/ART) dan Surat Perjanjian Kerjasama (SPKS). Aturan tidak tertulis yang dimiliki Kelompok Tani Hutan Santuso II berupa kesepakatan-kesepakatan yaitu kesepakatan setiap anggota diharuskan menjual kapulaga kering kepada Kelompok Tani Hutan Santuso II, melaporkan penjualan kapulaga kepada Kelompok Tani Hutan Santuso II dan kesepakatankesepakatan tersebut jika dilanggar oleh anggota, anggota diberi sanksi berupa teguran.

Kepercayaan yang muncul pada Kelompok Tani Hutan Santuso II didasari hubungan antara anggota kelompok tani dengan institusi yang saling bekerjasama. Kerjasama yang dilakukan diharapkan dapat bernilai positif bagi perkembangan kapulaga. Kerjasama yang dilakukan terdapat kewajiban dan tanggungjawab bersama. Kelompok Tani Hutan Santuso II percaya dengan membudidaya kapulaga dapat memberikan penghasilan tambahan, kepercayaan tersebut telah dibuktikan sendiri oleh anggota kelompok tani. Kepercayaan tersebut menimbulkan adanya harapan yang terkandung dalam kelompok seperti harga kapulaga yang bisa meningkat, memberikan penghasilan tambahan, dapat memperluas lapangan pekerjaan serta dengan budidaya kapulaga yang dilakukan Kelompok Tani Hutan Santuso II dapat memberikan hal positif bagi Desa Sumberpakem.

\section{DAFTAR PUSTAKA}

Fukuyama, F. (2010). Trust Kebijakan Sosial Dan Penciptaan Kemakmuran. Yogyakarta: CV. Qalam Yogyakarta.

Lawang, R. M. Z. (2004). Kapital Sosial. jakarta: Fisip UI Press.

Miles, M. B., \& Huberman, A. M. (1992). Analisis Data Kualitatif. Jakarta: UI-Press.

Putnam, R. D. (1995). Tuning In, Tuning Out: The Strange Disappearance of Social Capital in America. PS: Political Science and Politics, 28(4), 664.

Regaty, H. A. (2017). Keberhasilan Kelompok Tani Sekar Mulyo dalam Memengaruhi Kebijakan Pemerintah Kota Batu Tahun 2009-2016. Jurnal Politik, 3(1), 90-107. https://doi.org/10.7454/jp.v3i1.57

Setiawan, B. R., \& Soejono, D. (2018). Nilai Tambah dan Prospek Pengembangan Agroindustri Kopi Herbal Kapulaga di Desa Sumberpakem Kecamatan Sumberjambe. UNEJ E-Proceeding Pembangunan Pertanian Dan Peran Pendidikan Tinggi Agribisnis: Peluang Dan Tantangan Di Era Industri 4.0, 27-44.

Undang Undang Republik Indonesia Nomor 41 Tahun 1999 Pasal 70. (1999). Kehutanan. Presiden Republik Indonesia, p. 47.

Usman, S. (2018). Modal Sosial. Yogyakarta: Pustaka Belajar. 